\title{
AIT annual report 1991
}

ANNE LEEMING

City University Business School, London, UK

\section{The journal for information technology}

The editors are very happy to report that the journal is growing steadily both in quality and availability. The quality and quantity of papers submitted to the journal has increased markedly. The refereeing process is working well; up to three referees arc being consulted per paper. We are extending our panel of referees and members of the Editorial Board across Europe and the Far East. Unfortunately, Paul Strassmann has had to retire from the Board due to the demands of his business. The board will have its first full meeting in early October.

Subscriptions are growing; the number of enquiries rises as we extend our range of subjects and themes. Volume 5 number 4 was a particularly successful issue. With the co-operation of Chapman \& Hall we are planning to pilot a scheme of special rates for student subscriptions in the coming academic year; the content of the journal is very relevant to many masters' programmes. If the pilot works we will consider extending it to other institutions.

We welcome contributions from authors under several headings:

(1) As refereed papers where the process is well established and involves a minimum of three referees and a time delay of not more than 3 months;

(2) As position papers on continuing research;

(3) As opinion papers on issues of importance to the business and IT community;

(4) As case studies of practice in the field;

(5) As management reports.

We accept conference reports and book reviews. Notices of future events such as conferences and seminars are being published.

\section{The annual conference}

In April a further AIT Conference was held at Sunningdale on the theme of improving the teaching practice within Information Systems. This was as usual a well attended and fruitful event thanks to the very able leadership of Colin Tully who chaired the event. Selected proceedings will be published in coming issues of Journal of Information Technology.

\section{Membership}

Following the survey undertaken at the end of 1990, it was decided, in the interests of efficiency and committee members' time, that the only class of membership offered should be by subscription to Journal of Information Technology. This enables association matters to be circulated via the journal. We are very grateful to Chapman \& Hall for their support in this matter.

\section{Other activities}

Sponsorship: we have agreed to be a sponsor of an IEE Conference next April at Oxford and a major sponsor of a $\mathrm{PhD}$ colloquium to be held at Gity University in September. This event is designed to provide a forum for research students in the Information Systems field and will select candidates for the 1991 ICIS conference in New York in December.

Co-operation with Henley Business School to put on a conference on Information Management in August 1992 is being actively pursued.

A bid to host the 1995 ICIS conference in London was unsuccessful due to the high cost of accommodation in London.

\section{Committee membership}

I am extremely grateful for the loyal attendance of the members of the hardworking executive committee at our four meetings throughout this year. I am sorry to have to report that due to pressures of business or distance or time, indeed any and every combination of those pressures, we have to bid farewell to John Hawgood, Peter Robinson, Guy Fitzgerald and Fred Mundle. Leaving the executive does not mean leaving the Editorial Board so we look forward to maintaining contact with them. In their place we are delighted to welcome Baggy Cox, Dan Remenyi, Ewan Sutherland and Ted Hutchin. The committee re-elected the officers as last year. I would like to express my gratitude to them for their unfailing source of good ideas as well as their support and hard work. 'The executive also owes much to Leslie Willcocks for his persistence and acute perception in putting together such interesting issues of the journal. Long may that continue.

Anne Leeming 